В. В. СУКАЧ, д-р геол. наук, завідувач відділу (Інститут геохімії, мінералогії та рудоутворення ім. М. П. Семененка НАН України), svital@ukr.net, https://orcid.org/0000-0002-4710-7230,

О. Б. БОБРОВ, д-р геол. наук, професор, головний геолог (ABMAV SubSahara (SL) Ltd), albobrov@ukr.net, https://orcid.org/0000-0001-7338-3602
V. SUKACH, Dr. Sci. (Geol.), Head of Department (M. P. Semenenko Institute of Geochemistry, Mineralogy and Ore Formation of NASU), https://orcid.org/0000-0002-4710-7230,

O. BOBROV, Dr. Sci. (Geol.), Professor, Chief Geologist (ABMAV Sub-Sahara

(SL) Ltd), albobrov@ukr.net, https://orcid.org/0000-0001-7338-3602

\title{
СОЛОНЯНСЬКЕ РУДНЕ ПОЛЕ - ПРІОРИТЕТНИЙ ОБ'ЄКТ ДЛЯ СТАРТУ ПРОМИСЛОВОГО ВИДОБУТКУ ЗОЛОТА В УКРАЇНІ
}

\section{SOLONE ORE FIELD - A PRIORITY TARGET FOR THE START OF GOLD MINING IN UKRAINE}

У статті подано стислий огляд головних золоторудних об’єктів України та закцентовано увагу на Солонянському рудному полі (СРП), яке розташоване у Середньопридніпровській субпровінції Українського щита (УЩ). На сьогодні в Україні відкрито 10 родовищ і понад 200 перспективних рудопроявів золота в межах металогенічних провінцій: Карпатсько-Кримської, Дніпровсько-Донецької та УЩ. Найбагатшою золотоносною провінцією є УЩ, ресурси якого оцінюються в не менш як 2400 т благородного металу. 3 них близько 1000 т зосереджені в межах СРП, де компактно розміщені золото-молібденові родовища Сергіївське та Балка Золота, а також рудопрояви золота Аполлонівський, Східноаполлонівський, Новий, Тетянин, Дорожній, Розрахунковий, Центральний, Сонячний. 3 огляду на сукупність сприятливих геолого-економічних умов, як-от значні ресурси благородного металу, проста геологічна будова, чіткий контроль та особливості локалізації зруденіння, вигідне географо-економічне положення тощо, СРП має реальні передумови для початку промислового видобутку золота в близькій перспективі. У межах рудного поля першочерговим об'єктом для розробки вважається Сергіївське родовище.

Ключові слова: родовища золота в Украӥні, Сурська зеленокам'яна структура, Солонянське рудне поле, Сергївське родовище, Балка Золота, поховані розсипи золота.

10 gold deposits and more than 200 occurrences have already been discovered in Ukraine. They are located within the Carpathian-Crimean, Dnipro-Donetsk and Ukrainian Shield metallogenic provinces. The richest gold-bearing province is the Ukrainian Shield (USh). Its gold resources are estimated at least 2,400 tons.

The main attention in the article is given to the Solone ore field (SOF), which is located within the Middle Dnipro subprovince of the USh province. Gold resources of SOF are about 1000 tons. We consider it is the most promising gold field for development, on the basis of next key factors: 1) gold mineralization is localized in high mineralized early Precambrian greenstone formations. Its analogue is the Porcupine gold field in Canada;2) simple geological structure with a clear ore-caused and ore-control role of subvolcanic acidic rocks; 3 ) two medium-scale gold-molybdenum deposits, Serhiivka and Balka Zolota, have already been discovered, as well as Apollonivka, East-Apollonivka, Novyi, Tetyana's, Dorozhnyi, Rozrakhunkovyi, Central, Soniachnyi gold ore occurrences; 4) localization in the industrially developed Dnipro region, which includes world-class deposits of iron (Kryvyi Rih basin) and manganese (Nikopol basin), as well as deposits of national level - titanium, aluminum, etc.; 5) Serhiivka and Balka Zolota deposits are complex gold-molybdenum deposits. In addition, molybdenite contains a high content of Re and Os, which can be extracted as very expensive components; 6) buried alluvial gold placers are known in the Paleogene rocks of the sedimentary cover above primary ore deposits.

In view of these favorable geological and economic circumstances, SOF has real prerequisites for the start of gold mining in the near future Serhiivka deposit is the high priority target for development within the Solone ore field.

Keywords: gold deposits in Ukraine, Sura greenstone structure, Solone ore field, Serhiivka deposit, Balka Zolota, buried gold placers.

Вступ. Поклади золота в Україні розроблялися з давніх-давен. Із загальних джерел відомо, що найстаріші гірничі виробки, яким приблизно 2500 років, було виявлено на Донбасі, на Березівському й Журавському золото-поліметалічних рудопроявах. Давні штольні, розсічки, шурфи епохи Римської імперії знайдено також у Карпатах і на Закарпатті, де золото видобувалося, ймовірно, разом з поліметалами. Тривав видобуток і впродовж XII-XVII століть. Зокрема, за часів Османської імперії на Закарпатті, як свідчать уривчасті дані, було видобуто й вивезено 20 т золота. У новітні часи, за непідтвердженими відомостями, 1893 року на ділянці Гострий Бугор у Нагольному кряжі в шахті завглибшки 70 м було видобуто 8,5 кг самородного золота.

На сьогодні в Україні відкрито 10 родовищ і понад 200 перспективних рудопроявів золота $[2,7,12]$. Вони розміщуються в межах трьох металогенічних провінцій, як-от КарпатськоКримська, Дніпровсько-Донецька і УЩ (рис. 1). Загальні ре-

В. В. Сукач, О. Б. Бобров, 2021, с. 3-12 сурси золота нині за різними оцінками становлять понад 3000 т. У Карпатсько-Кримській та Дніпровсько-Донецькій провінціях прогнозується по 300-400 т, а близько 2400 т припадає на УЩ, де поклади золота було виявлено лише в другій половині XX ст.

Як бачимо, УЩ - найбагатша золотоносна провінція України, хоча тривалий час його вважали безперспективним на благородний метал. Вперше самородне золото в архей-протерозойських метаморфічних породах УЩ виявила наприкінці 60-х років XX сторіччя Н. М. Гаєва та ін. [8]. Відтак спеціалізовані пошуки благородного металу розгорнулися майже на всій території УЩ. Це дало змогу наприкінці XX ст. відкрити цілу низку родовищ (Майське, Клинцівське, Юр'ївське, Сергіївське, Балка Золота, Балка Широка, Сурозьке), десятки рудопроявів і сотні пунктів мінералізації та порушити питання щодо створення власної золотодобувної галузі промисловості [13]. Два з перелічених родовищ, Сергіївське та Балка Золота [6, 21], розміщуються в межах СРП [9, 15-17] на півдні Сурської зеленокам'яної структури (ЗКС) або поясу. Загальний ресурсний потенціал СРП становить близько 1000 т. 


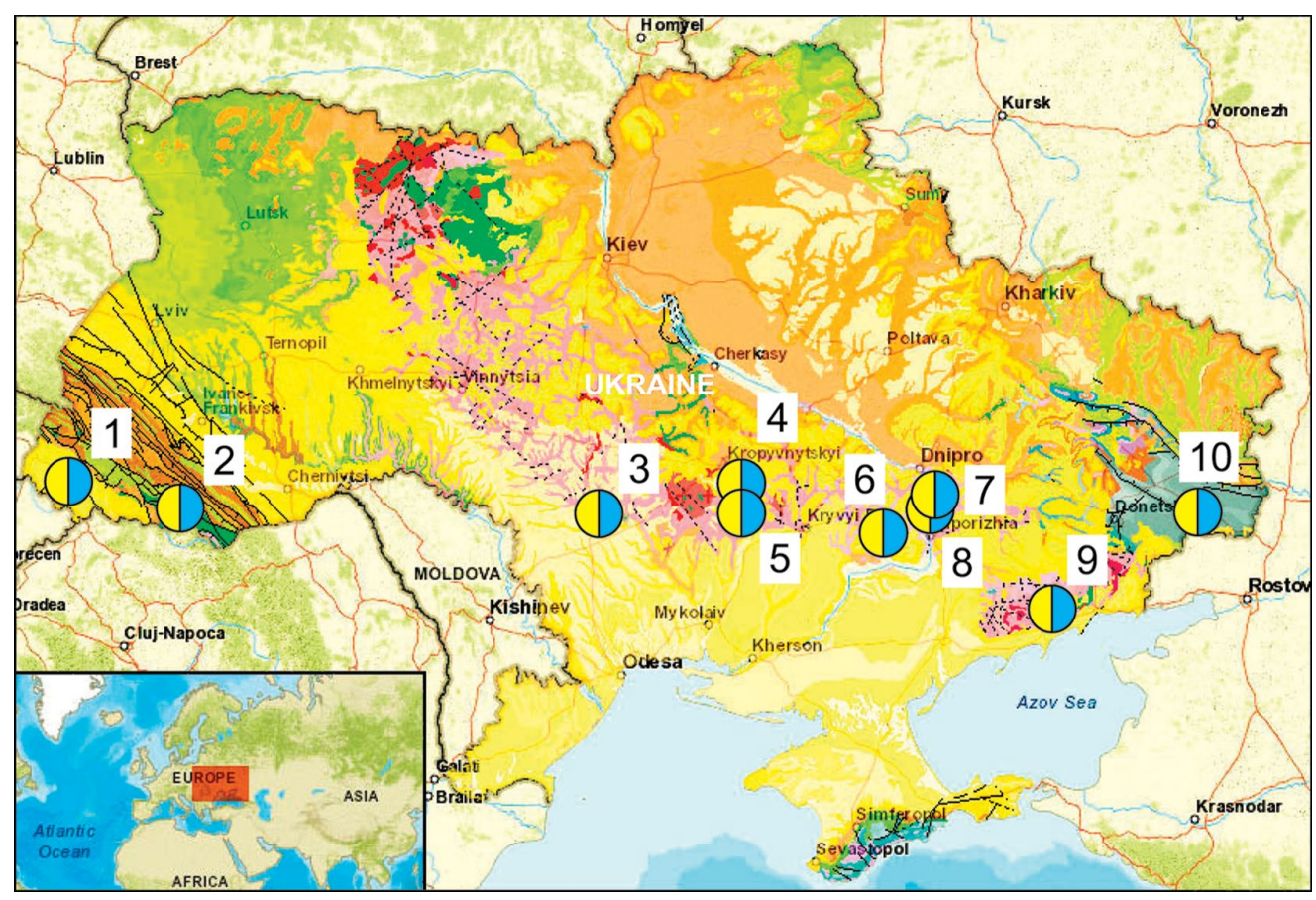

Рис. 1. Родовища золота: 1 - Мужіївське, 2 - Сауляк, 3 - Майське, 4 - Клинцівське, 5 - Юр”ївське, 6 - Балка Широка, 7 - Балка Золота, 8 - Сергіївське, 9 - Сурозьке, 10 - Бобриківське. Використано матеріали ДНВП “Геоінформ України” https:/geoinf.kiev.ua

та Балка Широка. Отримані дані загалом підтвердили заявлені ресурси золота, але наявні капіталовкладення були явно недостатніми для завершення розвідки й початку видобутку. Тож, не отримавши швидкого й дешевого результату, ці та інші компанії йшли з ринку або припиняли діяльність.

Важливо зазначити, що в період найбільшої активізації робіт на родовищах України наприкінці XX ст. ринкова ціна тройської унції золота не перевищувала 300 доларів США. Тепер (станом на серпень 2021 р.) вона стабілізувалася на рівні 1750-1800 доларів США.

3 огляду на таку сприятливу економічну кон'юнктуру, золоторудні родовища України сьогодні можуть стати вельми привабливими й рентабельними об'єктами для інвестицій, зокрема, з боку таких гірничодобувних компаній, як Newmont Goldcorp, Barrick Gold, AngloGold Ashanti та інших світових лідерів з видобутку золота.

Мета статті. Робота присвячена стислому огляду головних золоторудних об'єктів України з акцентуванням на Солонянському рудному полі, що розглядається як найперспективніше серед інших завдяки значним ресурсам золота, простій геологічній будові, чіткому контролю та особливостям локалізації зруденіння, вигідному географо-економічному положенню тощо. 3 огляду на всю сукупність сприятливих умов СРП має реальні перспективи для початку промислового видобутку золота в близькому майбутньому.

1. Загальний стан проблеми. Попри великий золоторудний потенціал України, жодне з родовищ не розробляється. Головна причина, на наш погляд, криється в недостатніх державних і приватних капіталовкладеннях, потрібних для довивчення та розвідки хоча б одного-двох найперспективніших об'єктів. Зазвичай вітчизняні та іноземні компанії, які планували (і планують) видобуток золота в Україні, сподівалися критично мінімальним коштом виконати розвідку і в стислі терміни вийти на промисловий видобуток. Зокрема, в середині 90-х років XX сторіччя державна акціонерна компанія "Укрзолото" i Ashurst Rosources International витратили 1,8 млн доларів США на геологорозвідувальні роботи 3 вивчення п'яти родовищ, якот Сергї̈вське, Клинцівське і Юр'ївьке, Балка Золота

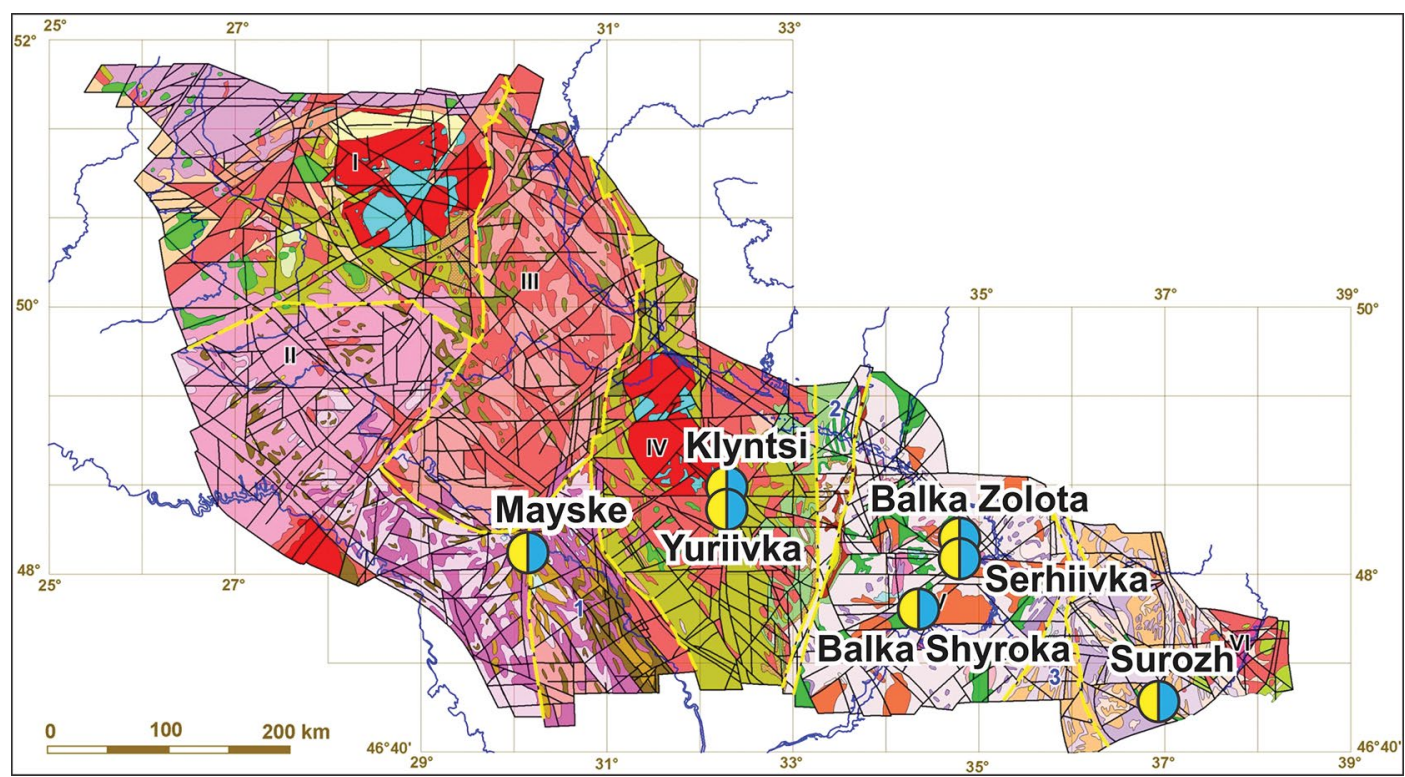

Рис. 2. Схема розміщення родовищ золота на схематичній геологічній карті Українського щита (Пояснювальна записка до “Кореляційної хроностратиграфічної схеми УЩ”, 2004) 
архейського віку (рис. 3) і має найбільший золоторудний потенціал серед інших субпровінцій [2, 10, 12-14]. За геолого-металогенічними ознаками вона цілковито відповідає високопродуктивним на золото світовим аналогам: ГЗО (провінціям) Канади, Австралії, Південної Африки. Руди золота виявлені в більшості зеленокам'яних структур регіону, серед яких центральне місце займає Сурська ЗКС. Саме в їі південній частині розміщується СРП [15-17]. Великі перспективи має також Чортомлицька ЗКС, де виявлено родовище Балка Широка й десятки рудопроявів. Високоперспективною, але менш вивченою є Верхівцівська ЗКС. Приазов'я також належить до розряду ГЗО, але мінералізація золота тут менш розвинена. Потенційно промислові поклади золота виявлено тільки в Сорокинській 3КС - Сурозьке родовище.

2.1 Солонянське рудне поле розміщується в Солонянському районі Дніпропетровської області. Воно охоплює південну частину Сурської ЗКС (рис. 4, 5), де компактно розміщуються золоторудні (з молібденом) родовища Сергіївське та Балка Золота [6, 19], а також рудопрояви Аполлонівський, Східноаполлонівський, Сонячний, Новий, Тетянин, Дорожній, Розрахунковий, Центральний, більш як 20 пунктів мінералізації та понад 150 геохімічних аномалій золота [15]. Загальна площа СРП становить близько 90 км².

СРП має порівняно просту геологічну будову [21]. Воно складене двома метаморфізованими, контрастними за складом вулкано-плутонічними асоціаціями (ВПА) мезоархею:

- ранньою (3,2-3,0 млрд років) аполлонівсько-сергї̈вською згідно з працею [18] або нижньою метатолеїт-габро-ді-

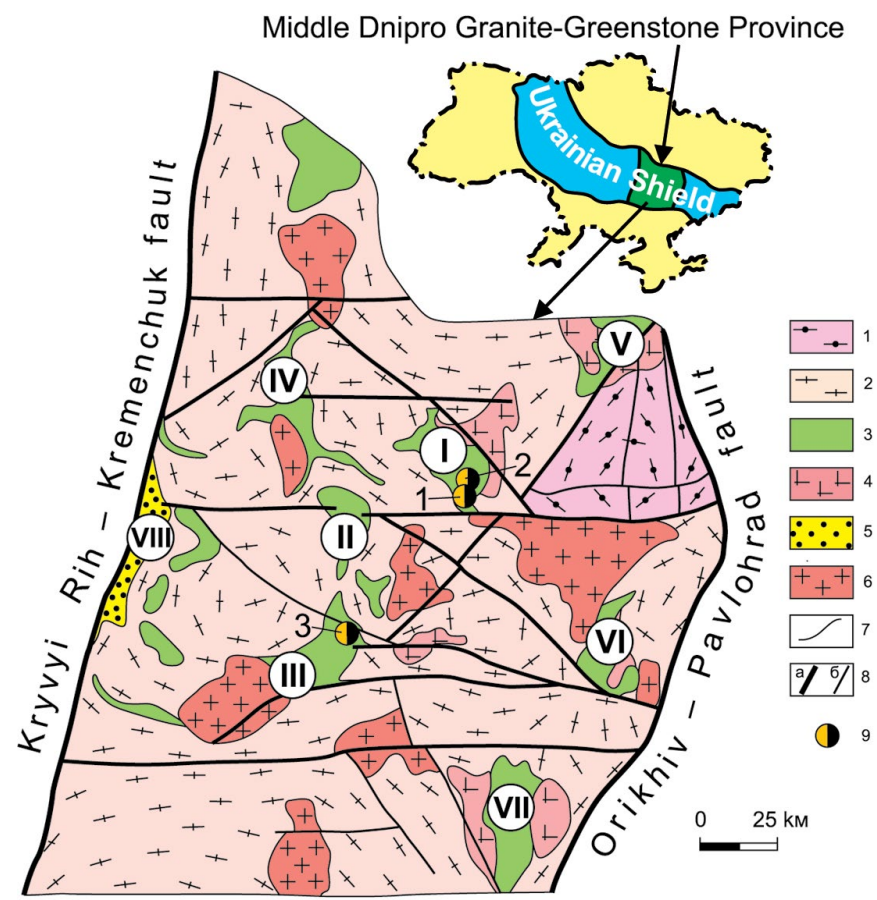

Рис. 3. Середньопридніпровська граніт-зеленокам'яна область (провінція)

1 - плагіомігматити з останцями гранулітів, 2 - плагіомігматити 3 ксенолітами амфіболітів, 3 - зеленокам'яні утворення, 4 - плагіограніти, 5 - метавулканогенно-осадові породи Криворізької структури, 6 - двопольовошпатові граніти, 7 - геологічні границі, 8 - розломи: а) регіональні та головні, б) другорядні; 9 - родовища: 1 - Сергіївське, 2 - Балка Золота, 3 - Балка Широка

Зеленокам'яні структури (пояси) і родовища золота: I - Сурська (Сергї̈вське і Балка Золота), II - Софіївська, III - Чортомлицька (Балка Широка), IV - Верхівцівська, V - Дерезуватська, VI - Конкська, VII - Білозерська, VIII - Криворізька (Кривбас) абазовою ВПА за працею [3] (вулканогенна парагенерація KT-1 метакоматіїт-толеїтової формації та комагматична їй перша фаза метагабро-діабазової плутонічної формації). Це метаморфізовані магматичні породи здебільшого основного складу ( 70 \% площі СРП), які представлені потоками метабазальтів і дайкоподібними інтрузивами та силами метагабро-долеритів;

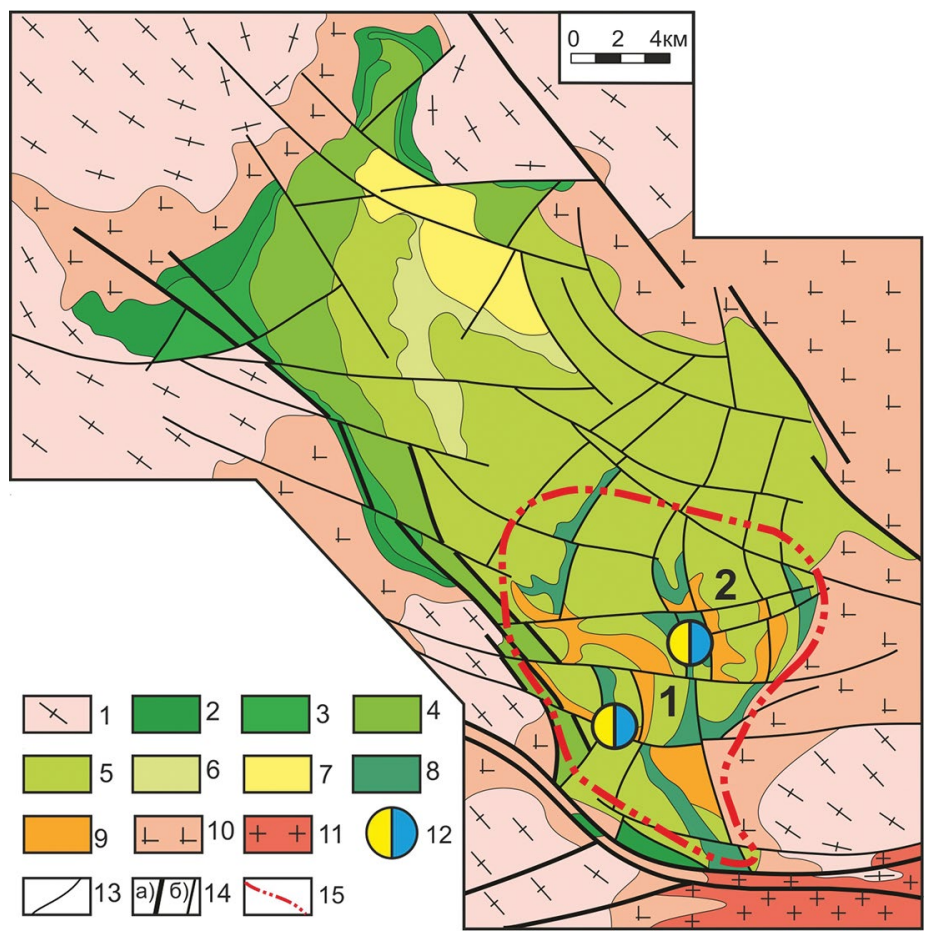

Рис. 4. Геологічна карта Сурської ЗКС

1 - мігматити, 2 - амфіболіти, 3 - метакоматіїти, 4 - метабазальти, метаосадки, метакоматіїти, залізисті кварцити (BIF); 5 - метабазальти, 6 - метакоматіїти, метабазальти; 7 - метатуфи базальтів, метатуфіти; 8 - метагабродолерити, 9 - метадацити, метаріодацити; 10 - плагіограніти, 11 - граніти, 12 - родовища золота: 1 - Сергіївське і 2 - Балка золота; 13 - геологічні границі, 14 - розломи: а) головні, б) локальні; 15 - межа Солонянського рудного поля

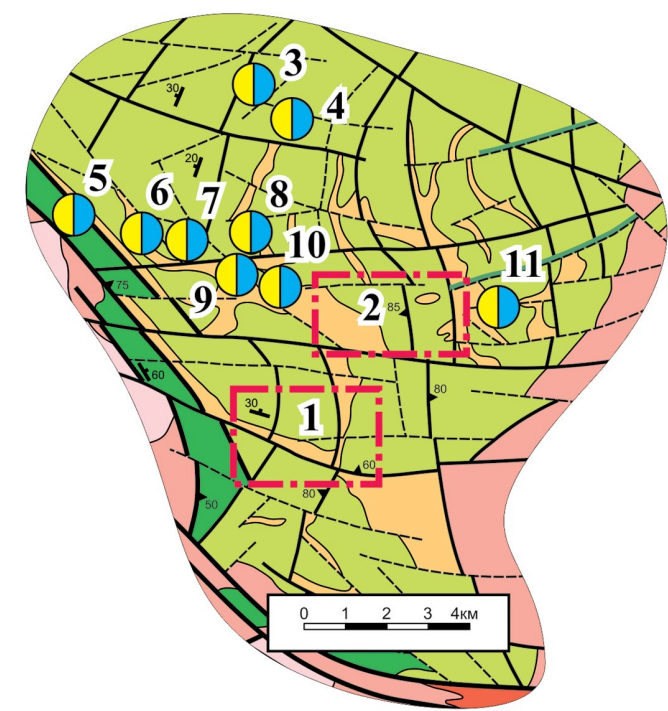

\section{Рис. 5. Геологічна карта Солонянського рудного поля}

Золото-молібденові родовища: 1 - Сергіївське, 2 - Балка Золота. Рудопрояви золота: 3 - Аполлонівський, 4 - Східноаполлонівський, 5 - Південнопетрівський, 6 - Сонячний, 7 - Новий, 8 - Розрахунковий, 9 - Центральний, 10 - Дорожній, 11 - Тетянин 
- пізньою (2,9-3,0 млрд років) солонянсько-сурською або метаріодацит-плагіогранітною ВПА за працями [3-5] (вулканогенна метаріодацитова і комагматична йй плутонічна тоналіт-плагіогранітова формаціі), що складає 30\% площі СРП. Вона представлена порфіровими метаморфізованими ріодацитами, дацитами, тоналіт-порфірами і порфіроподібними тоналітами у вигляді субвулканічних тіл і дайок, зрідка штоків і невеликих масивів.

Породи кислого складу пізньої ВПА проривають метабазити ранньої ВПА, а щодо зруденіння золота вони є рудоконтролювальними та рудогенерувальними [3-5, 15-18]. Важливо зазначити, що метаріодацит-плагіогранітна ВПА з огляду на їі структуротвірне та металогенічне значення відіграє важливу, унікальну роль не лише для Сурської ЗКС зокрема, а й для Середньопридніпровської ГЗО загалом. Адже ділянки поширення цієї ВПА в межах практично кожної ЗКС характеризуються появою складчастих форм високих порядків, комбінацією складчасто-розривних деформацій із синхронним проявом рудно-метасоматичних перетворень під впливом насичених газами флюїдних систем. Саме завдяки термально-метасоматичим процесам здійснювалося як первинне відкладення, так і ремобілізація рудних компонентів, їхн переміщення, перерозподіл та збагачення. Внаслідок цього в ЗКС сформувалася ціла низка золоторудних родовищ (Сергї̈вьке, Балка Золота, Балка Широка) і рудопроявів (Гвардійський, Вільнохутірський та ін.) [20]. Що стосується СРП, то ареал розвитку утворень пізньої ВПА чітко окреслює площу розвитку золоторудної мінералізації та власне визначає геологічні межі рудного поля $[15,16]$.

На поверхні кристалічних порід розвинена площинна кора вивітрювання потужністю від 30 до 80 м. Ії перекривають осадові відклади палеогенової, неогенової і четвертинної систем (суглинки, глини, піски) потужністю 10-50 м.

2.1.1 Сергївське золото-молібденове родовище [2, 19,21] розміщується в південній частині СРП. Зруденіння золота приурочено до субвулканічного тіла метадацитів пізньої ВПА (рис. 6), яке контролюється зоною субширотного розлому й ортогонально січе основні породи ранньої ВПА. Продуктивна мінералізація

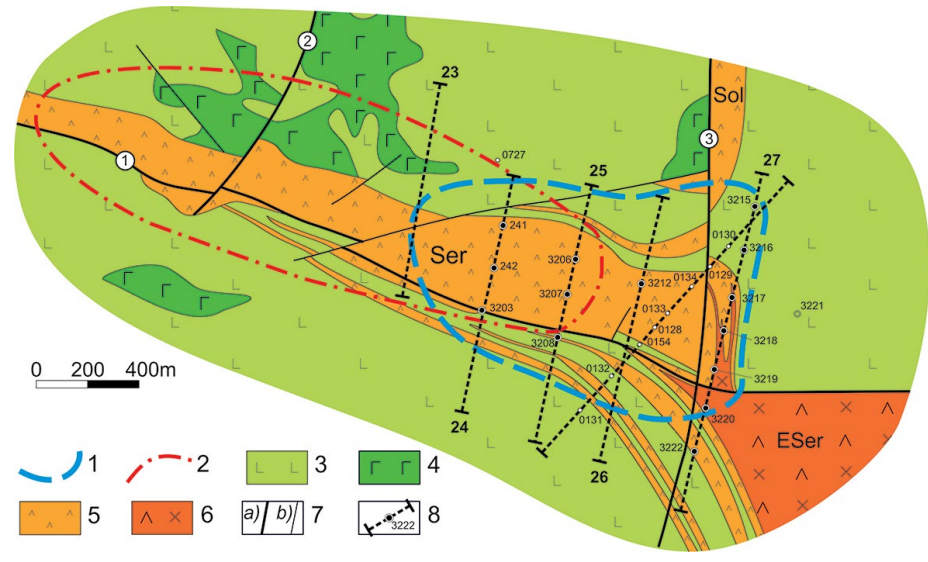

Рис. 6. Геологічна карта Сергї̈вського золото-молібденового родовища

Ареали розвитку мінералізації: 1 - молібдену (синій контур), 2 - золота (червоний контур). Рання ВПА: 3 - метабазальти, 4 - метагабро-долерити, метагабро; пізня ВПА: 5 - метадацити, метаріодацити, 6 - тоналіт-порфіри, порфіроподібні тоналіти; 7 - розломи (а) і геологічні границі (b); 8 - профілі буріння, свердловини та їхні номери. Цифри в кружках - головні розломи: 1 - Північносергіївський, 2 - Центральносергіївський, 3 - Східносергї̈вський. Пізня ВПА: Сергіївське (Ser) і Солонянське (Sol) субвулканічні тіла метадацитів, метаріодацитів; Східносергіївський (ESer) масив тоналіт-порфірів, порфіроподібних тоналітів локалізується зазвичай у базитах, частково - у кислих породах. Рудні тіла розміщуються переважно в інтенсивно розсланцьованих, метасоматично змінених породах. Навколорудні зміни представлені середньо-низькотемпературними метасоматитами кислотного вилуговування з калієвою спеціалізацією.

Виокремлюються три речовинно-морфологічні типи золоторудних тіл:

1) зони прожилково-вкрапленої сульфідної мінералізації. Вміст сульфідів (пірит, піротин, халькопірит, сфалерит, галеніт, арсенопірит) варіює від 1 \% до 40 \%. Потужність зон у роздувах досягає 10 м і більше;

2) кварц-карбонатні, карбонат-кварцові й амфібол-кварцкарбонатні жили та лінзи потужністю до 5 м і до 100 м за простяганням. Уміст сульфідів становить 3-5 \%. Золото концентрується в зальбандах та екзоконтактах жильних утворень;

3) найпоширеніший випадок, коли жили й лінзи 2-го типу містяться в зонах 1-го типу. Найпоширеніші різновиди золотих руд показано на рис. 7.

Всього на родовищі оконтурено 23 рудні тіла із середнім умістом золота 7,6 г/т. Вони мають потужність 2 м, за простяганням сягають до 100 м, а за падінням - 250-350 м. Рудні тіла продовжуються за здійманням у корі вивітрювання, по-



Рис. 7. Зразки типових руд золота Сергї̈вського родовища: а - біотит-карбонатно-кварцова жила в альбітизованих метабазальтах; b - золото-кварцова жила з низьким умістом сульфідів (1-3 \%); с - кварц-сульфідна жила в метаріодацитах; $\mathrm{d}$ - суцільна сульфідна руда 
тужність якої становить 20-60 м. 3 глибиною вміст золота в рудах залишається стабільним. Самородне золото (рис. 8) переважно високопробне - до 930. За даними мінералогічних і технологічних досліджень руд основний обсяг золота (85-90 \%) знаходиться у вільному стані.

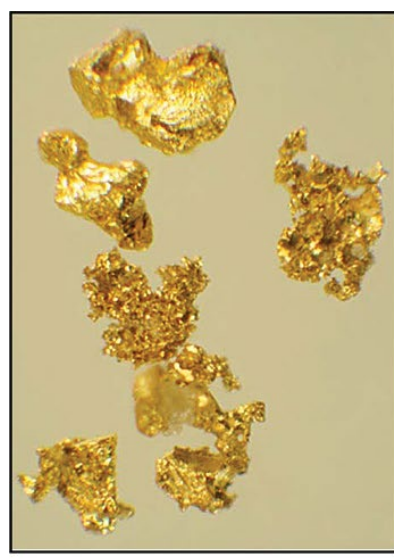

a

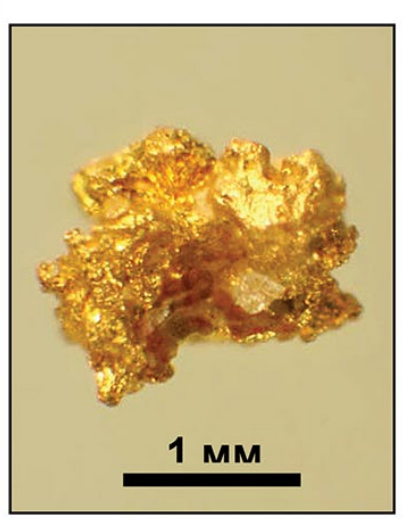

b

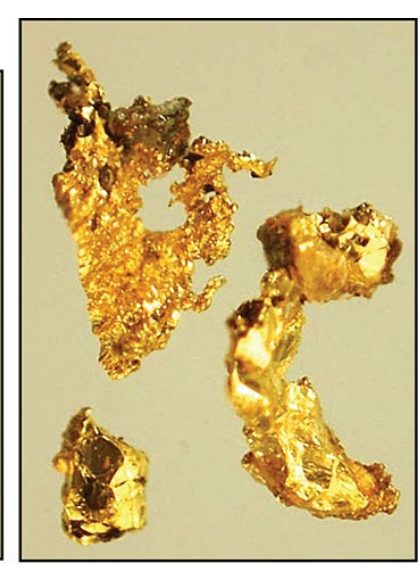

c
Рис. 8. Самородне золото Сергї̈вського родовища: a, b - сверд. 3210, гл. 91,3-94,8 м; с - технологічна проба № 11

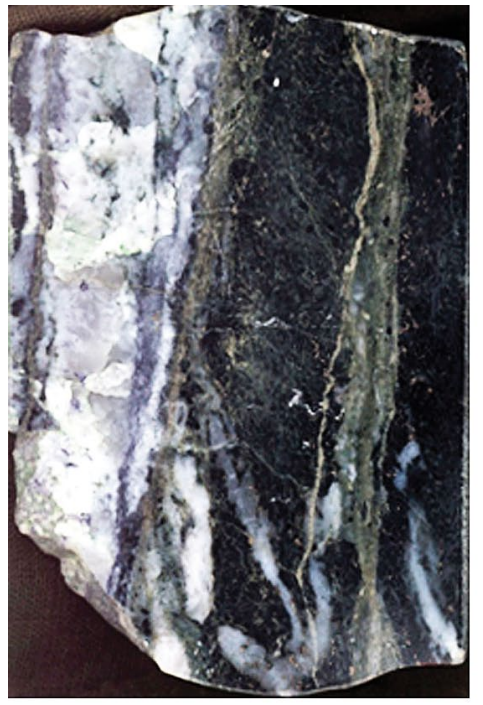

a

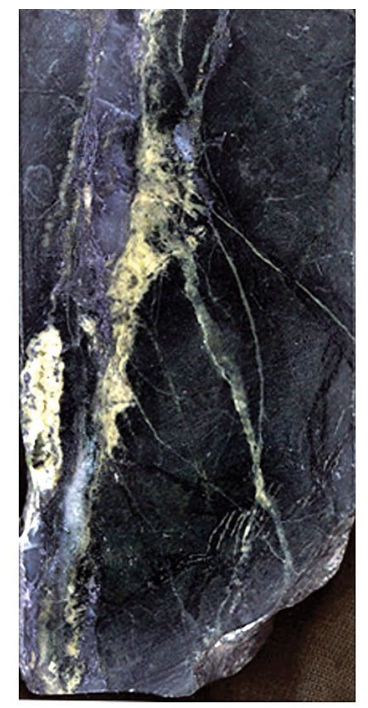

b

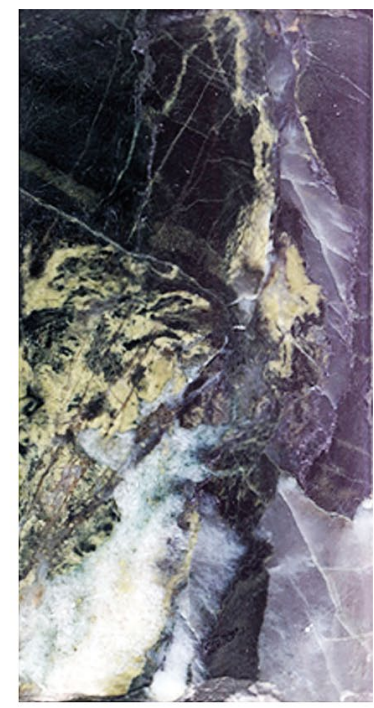

c
Рис. 9. Молібденові руди східного флангу Сергї̈вського родовища:

а - карбонатно-кварцова жила 3 молібденітом у метабазальті (сверд. 3213, гл. - 317,5 м), b - кварцовий прожилок з піритом, молібденітом у метабазальті (сверд. 3213, гл. 264 м), c - молібденіт, кварц, карбонат, пірит у метабазальті (сверд. 3213, гл. 266,8 м)

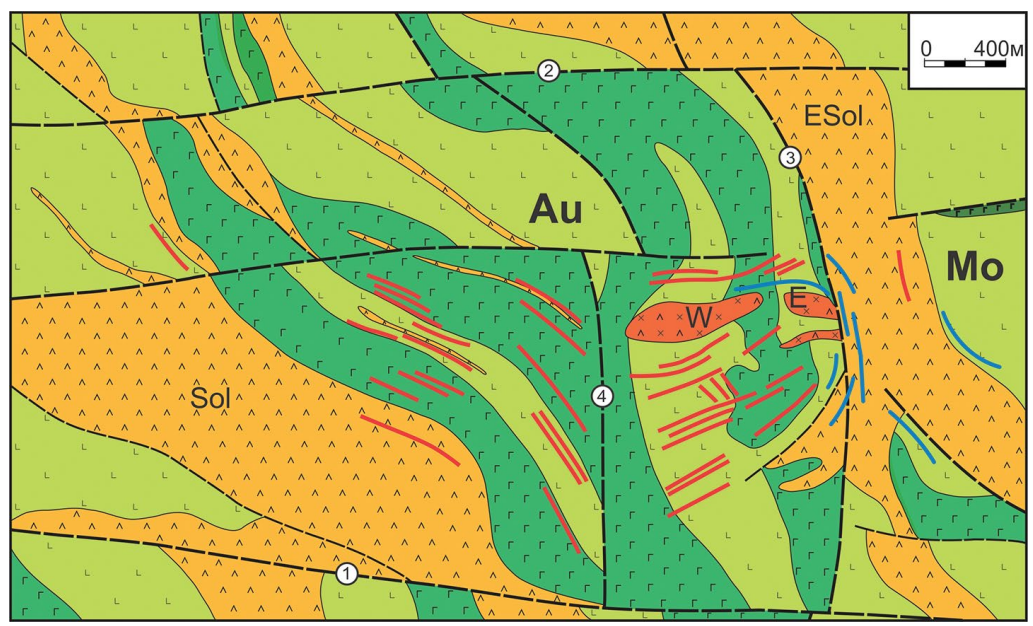

На східному фланзі родовища золоте зруденіння поступово змінюється молібденовим лінійно-штокверкового типу. Це хаотична мережа малопотужних кварцових, карбонат-кварцових прожилків 3 лінзочками і вкрапленістю сульфідів (2-5 \%) та молібденіту. Молібденіт локалізується в розсланцьованих і метасоматично змінених метадацитах, метаріодацитах, тоналіт-порфірах, а також метабазитах і їхніх ксенолітах у кислих породах (рис. 9). Виявлено та оконтурено 20 прожилкововкраплених рудних зон потужністю до 100-150 м. Бортовий уміст молібдену для рудних зон становить $0,01 \%$, а для рудних тіл, які виокремлюються в їхніх межах, 0,05 \%. Крім цього, у молібденіті діагностовано підвищений уміст ренію (від 93,8 до 229,5 г/т) та осмію (від 0,8 до 277,77 г/т).

За нашими даними запаси й ресурси золота в центральній частині Сергї̈вського родовища становлять не менш як 50 т. Ресурси молібдену в східній частині родовища оцінюють у 63 тис. т за середнього вмісту $0,023 \%$, ресурси золота - у 32 т (Л. О. Рязанцева та ін., 2004). На родовищі здійснено бурову розвідку. Для старту експлуатації потрібна дорозвідка підземними гірничими виробками.

2.1.2 Золото-молібденове родовище Балка Золота $[6,21]$ розміщується в центральній частині СРП на відстані приблизно 4,5 км північніше від Сергївського родовища. Геологічну будову родовища як складової частини СРП також визначають дві мезоархейські ВПА: рання аполлонівсько-сергіївська (потоки метабазальтів, дайкоподібні тіла метагабро-долеритів) і пізня солонянсько-сурська (субвулканічні порфірові метадацити, тоналіт-порфіри, порфіроподібні тоналіти, фельзитоподібні породи).

Золоте зруденіння (рис. 10) просторово локалізується в зоні розміром $2,5 \times 1,2$ км, що утворена накладанням екзоконтактів Солонянського та Східносолонянського субвулканічних тіл пізньої ВПА. Рудовмісні структури - це мінералізовані зони в розсланцьованих метабазальтах і метагабродолеритах. У межах мінералізованих зон золоторудні тіла виокремлюються за максимальним скупченням жильно-прожилкового матеріалу та помірним розвитком сульфідів. Рудні тіла представлені трьо-

Рис. 10. Геологічна карта золото-молібденового родовища Балка Золота

Рудні тіла золота позначені червоним кольором, молібдену - синім. Цифри в кружках - номери розломів: 1 - Південносолонянський, 2 - Солонянський, 3 - Золотобалківський, 4 Центральнозолотобалківський. Пізня ВПА: Sol - Солонянське та ESol - Східносолонянські субвулканічні тіла метадацитів, метаріодацитів; $\mathrm{W}$ - Західний і $\mathrm{E}$ - Східний штоки порфіроподібних тоналітів. Інші умовні позначення див. на рис. 6 
ма речовинно-морфологічними типами: 1) кварц-карбонатні жили й лінзи; 2) зони прожилково-вкрапленої мінералізації; 3) штокверк. Всього виявлено близько 70 рудних тіл середньою потужністю 1,6 м за варіацій від 0,1 до 19,3 м із середнім умістом золота 6,4 г/т. Сульфіди в рудах наявні в кількості 1-5 \%.

Мінералізація молібдену, як і на Сергї̈ському родовищі, прилягає до східного флангу власне золоторудного об'єкта. Молібденіт локалізується в березитизованих кислих породах пізньої ВПА і пропілітизованих основних метавулканітах ранньої ВПА. Рудоносні зони насичені прожилками кварцового, пірит-анкерит-кварцового, карбонат-кварцового складу. Самородне золото (рис. 11) за морфологією і складом аналогічне золоту Сергіївського родовища.

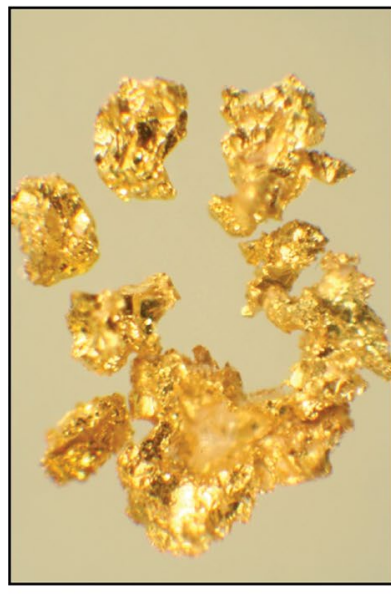

a

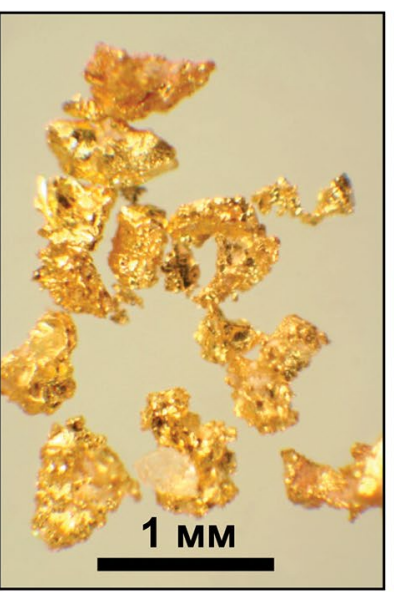

b

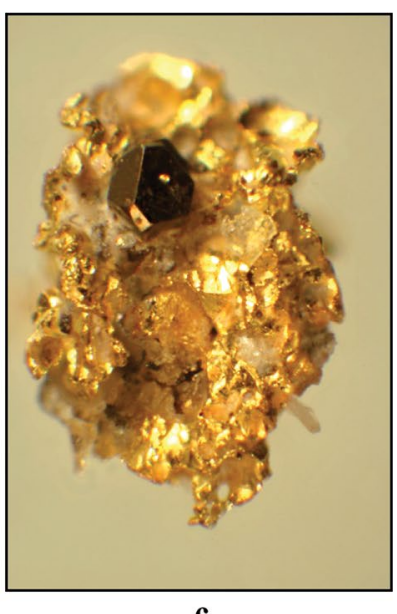

Рис. 11. Самородне золото родовища Балка Золота: a, b - сверд. 971, гл. 58,8-60 м; c - вкраплення кристала магнетиту в золоті, сверд. 544, гл. 72 м

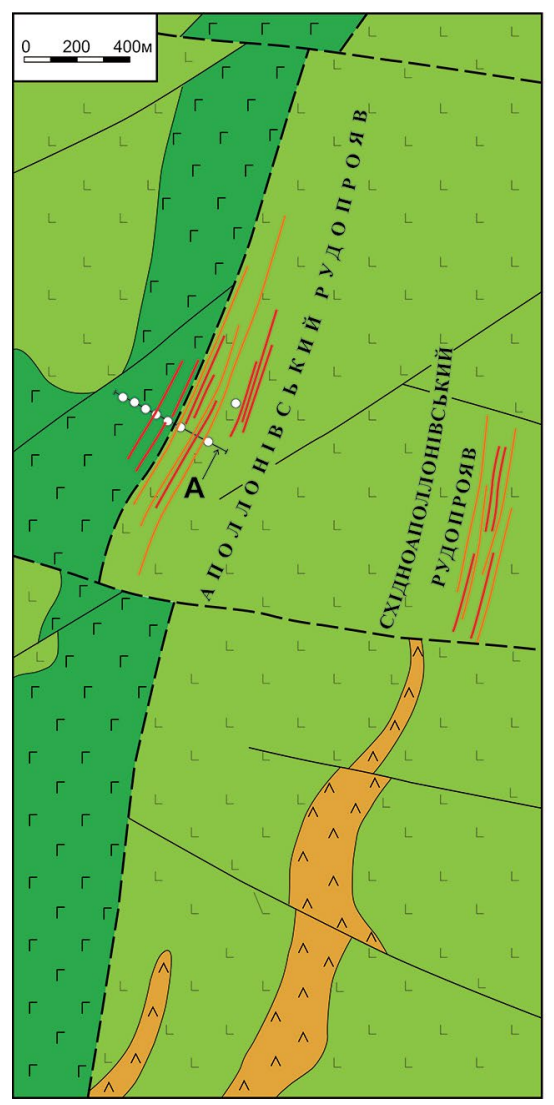

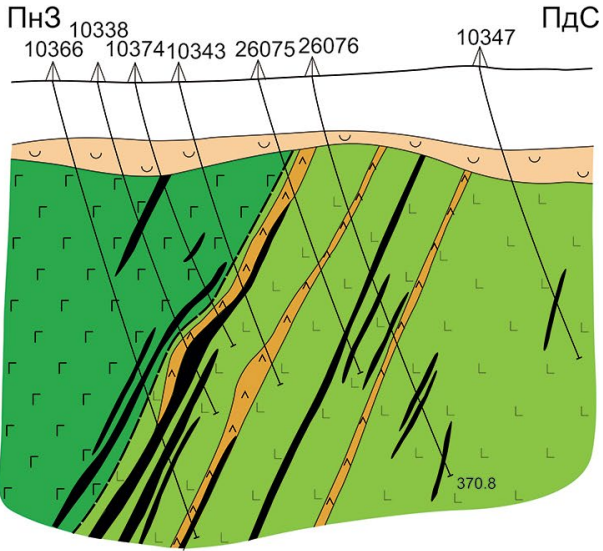

Рис. 12. Геологічна карта і розріз рудопроявів золота Аполлонівський і Східноаполлонівський

Умовні позначення див. на рис. 6,10
Родовище Балка Золота, порівнюючи із Сергї̈вським, вивчене менше й умовно перебуває на пошуково-оцінювальній стадії геологорозвідувальних робіт. Прогнозні ресурси золота становлять 67,5 т, молібдену - 43 тис. т за середнього місту 0,022 \% (Л. О. Рязанцева та ін., 2004). виявлення середнього за масштабами родовища, аналогічно-

2.1.3 Рудопрояви Аполлонівський і Східноаполлонівський розміщуються в північній частині СРП на відстані 2 км один від одного. Обидва об'єкти локалізуються в субмеридіональних тектонічних зонах. Приурочені до серії дайок метадацитів пізньої ВПА потужністю від 1-3 м до 27 м (рис. 12), що інтрудують ранню ВПА субзгідно до витягнених інтрузій метагабро-долеритів [15-17].

Мінералізація Аполлонівського рудопрояву приурочена до зони субмеридіонального розлому й контролюється трьома дайками метадацитів. Зруденіння локалізується в розсланцьованих, березитизованих метадацитах, зрідка - у сульфідизованих і карбонатизованих метагабро-долеритах і метабазальтах. Рудні тіла характеризуються розвитком кварцових і карбонат-кварцових прожилків, зрідка лінзованих жил. На рудопрояві виявлено 11 рудних тіл: середня потужність - 1,9 м, середній уміст золота - 4,6 г/т. Зазначимо, що вміст сульфідів у рудах (пірит, піротин) високий та іноді сягає $65 \%$.

Східноаполлонівський рудопрояв пов'язаний із субмеридіональними малопотужними (3-12 м) дайками дацитів і фельзитоподібних порід, що вкорінилися узгоджено 3 простяганням потоків метабазальтів і метадолеритів ранньої ВПА. Золоторудна мінералізація тяжіє до інтенсивно змінених сульфідизованих (пірит, піротин) порід 3 кварц-карбонатними прожилками. На відміну від Аполлонівського рудопрояву, сумарний уміст сульфідів дещо нижчий і становить $10-30 \%$. На рудопрояві розкриті чотири рудні тіла із середньою потужністю 1,2 м і середнім умістом золота 4 г/т.

2.1.4 Рудопрояв Розрахункий (рис. 13) локалізується в центральній частині СРП, на захід від родовища Балка Золота. Золоте зруденіння розміщується в метадацитах пізньої ВПА [15, 17], що утворюють витягнуте, овалоподібне субвулканічне тіло, яке ідентифікується як нек. Він прориває потоки базальтів ранньої ВПА, що містять поодинокі прошарки метатуфів і метатуфітів.

Рудні тіла представлені окремими кварцовими жилами потужністю до 1,7 м або їніми серіями. Одиничними свердловинами виявлено вісім рудних тіл, потужність яких досягає $1,7 \mathrm{M}$, а вміст золота варіює від 1 г/т до 25,2 г/т.

2.1.5 Поховані розсипи в осадовому чохлі. У межах СРП, крім корінного зруде- 

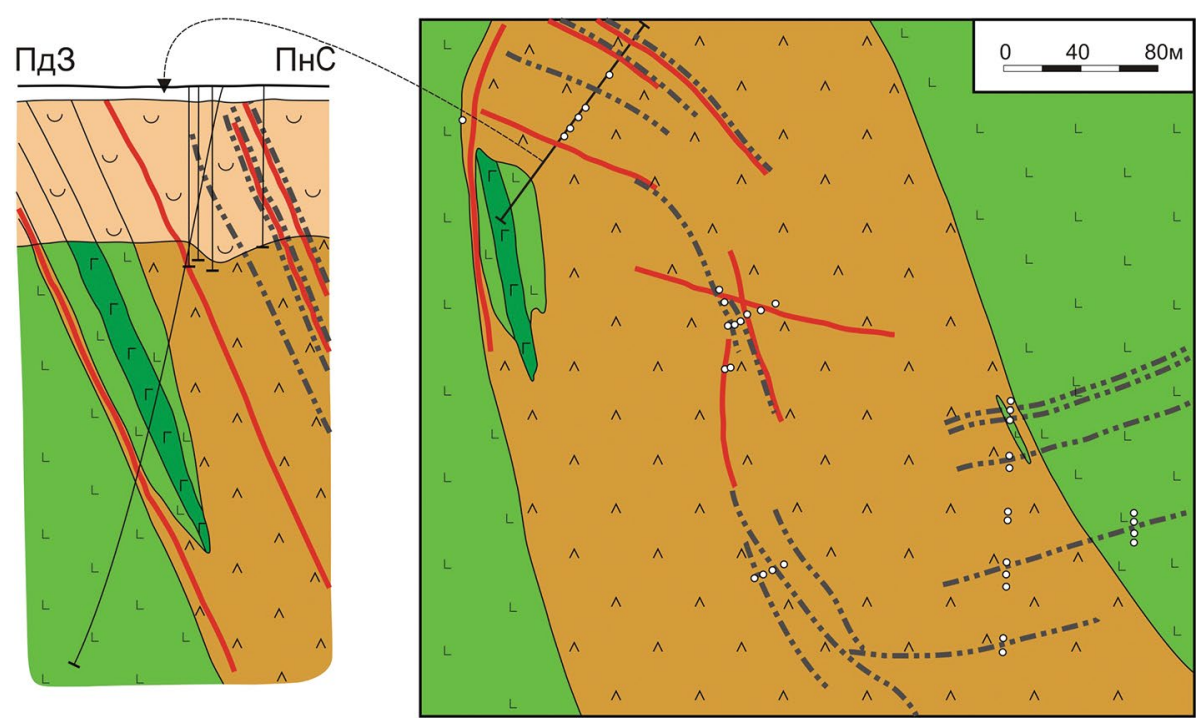

Рис. 13. Геологічна карта і розріз рудопрояву золота Розрахунковий

Умовні позначення див. на рис. 6,10

ніння, широкий розвиток мають розсипні концентрації золота в осадовому чохлі. Вони приурочені до похованих палеогенових алювіальних відкладів палеогену бучацької серії. Виявлено два потенційно промислові розсипи: Дніпровський і Сергіївький [15]. Вони розміщуються в зоні ближнього знесення корінних родовищ Балка Золота та Сергї̈вське відповідно.

Дніпровський розсип залягає над західним флангом корінного родовища Балка Золота (рис. 14). У плані контури розсипу чітко підпорядковуються конфігурації похованої річкової долини. Розсип має витягнену звивисту, стрічкоподібну форму з поступовим розширенням вниз за течією давньої річки. В межах розсипу виявляються збагачені самородним золотом “струмені” та “гнізда”. Один з найвивченіших і найбагатших золотоносних “струменів” має довжину 1100 м, ширину 17 м і середній уміст золота - 10,02 г/м³. Кількість золота в цьому “струмені” оцінюється в понад 200 кг, а ресурси металу загалом у Дніпровському розсипі становлять 1,2 т. Потужність продуктивного горизонту варіює від 0,2 до 5,4 м. Глибина залягання розсипу на різних відрізках палеодолини неоднакова й змінюється від 37 до 81 м.

Сергївський розсип розміщується над південним флангом корінного родовища Сергіївське. Самородне золото кон- центрується в русловій фації невеликого палеогенового водотоку, що належить до тієї самої річкової системи, що й палеодолина Дніпровського розсипу. Продуктивний горизонт залягає на глибині 57 м, його потужність становить 2,4 м, а вміст золота - 14,16 г/м³. Зазначимо, що ступінь вивченості Сергї̈вського похованого розсипу набагато поступається Дніпровському, де в 90-х роках ХХ сторіччя виконувалися спеціалізовані пошуки та дослідно-методичні роботи з підземного видобутку золота методом гідротранспорту керна буровим комплексом КГК-100.

2.2 Родовище Балка Широка розміщується в північно-східній частині Чортомлицької ЗКС [2]. Адміністративно - це Нікопольський район Дніпропетровської області.

У геологічній будові родовища беруть участь типові зеленокам'яні утворення: метавулканіти основного, ультраосновного, кислого, зрідка середнього складу з прошарками метавулканогенно-осадових порід і залізистих кварцитів. Мінералізація приурочена до зон дроблення, тріщинуватості, розвитку кварцових, кварц-карбонатних, кварц-карбонат-сульфідних прожилків. Характерним є також розвиток метасоматитів лиственіт-березитового типу. Мінералізовані зони мають пластувату морфологію (потужність 7-30 м), залягають субвертикально, узгоджено з умісними породами та простежуються на глибину до 800 м, а за простяганням - на 3500 м. Зруденіння контролюються поперечними розломами, флексурами типу “кінського хвоста”.

Виокремлюються три основні мінеральні типи руд:

1) золото-сульфідно-залізистий у залізистих кварцитах. Залізисті кварцити є золотоносними, якщо поєднані з внутрішніми зонами лиственітів і представлені кварц-сульфідною брекчією з магнетитом;

2) золотополіметалічний зі сріблом у сланцево-базитовій пачці. Вміст срібла досягає 430 г/т;

3) золото-кварцовий малосульфідний в ультрабазитах.

Середній уміст золота в рудних тілах становить 5,3 г/т. Потужність рудних перетинів варіює від 0,5 до 3-4 м. Ресурси золота оцінюються в понад 36 т.

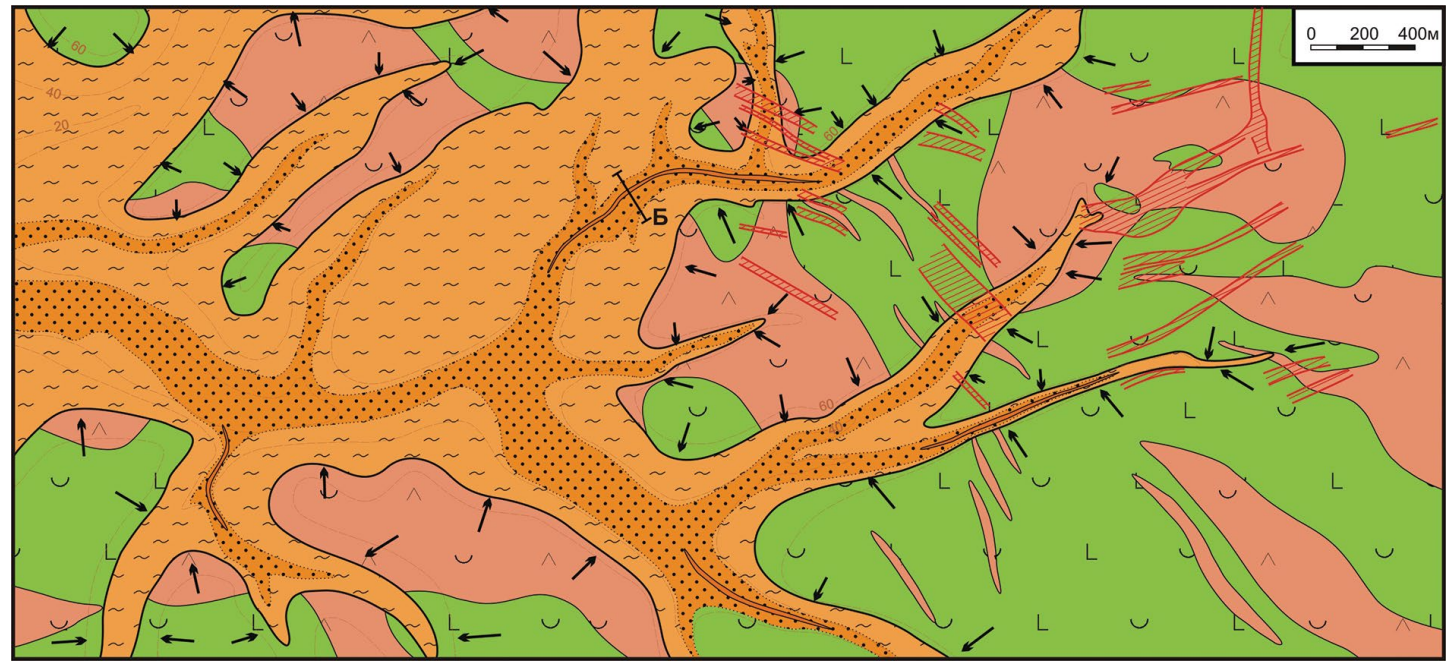

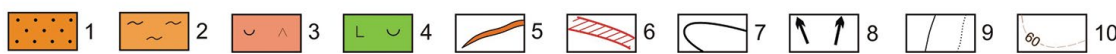

Рис. 14. Геологічна карта похованого Дніпровського розсипу золота над корінним родовищем Балка Золота 1 - золотоносна руслова фація (пісок, галька, валуни, глина), 2 - долинна фація (глина, вугілля, каолін); кора вивітрювання по: 3 - основних і 4 - кислих породах, 5 - збагачені золотом "струмені, 6 - золоторудні зони в корінних породах, 7 - контур палеогенових відкладів бучацької серії, 8 - напрямок знесення продуктів денудації корінних порід, 9 - геологічні та літолого-фаціальні границі, 10 - ізолінії поверхні кристалічних порід 
У середині 90-х років ХХ сторіччя на родовищі було розпочато розвідку й проходження вертикального шахтного стовбура, який сягнув глибини майже 170 м. Наразі всі гірничі виробки перебувають на “мокрій консервації,'тобто затоплені.

2.3 Сурозьке родовище - головний золоторудний об’єкт Приазовської субпровінції УЩ. Воно розміщується в Бердянському районі Запорізької області. Золоторудна мінералізація локалізована в Сорокинській ЗКС [1], на перетині розломів північно-західного й північно-східного простягання. Рудовмісна зеленокам'яна асоціація - це залізисті кварцити, метабазальти, метакоматіїти, метаріодацити й сланці (метаосадові породи).

Рудоносні зони й рудні тіла представлені пластовими тілами окварцьованих і сульфідизованих метасоматитів у катаклазованих, брекчійованих сланцях, амфіболітах, магнетитових кварцитах $[1,2,11,12]$. Вони узгоджено залягають 3 умісними породами, часто приурочені до контактів порід різного складу. Зрідка трапляються рудні кварцові жили потужністю до 1,2 м з умістом золота понад 18,2 г/т. У прожилково-вкраплених зонах із сульфідною мінералізацією вміст нижчий і становить 1,0-7,8 г/т.

Родовище розвідане свердловинами, а в місцях виходу на денну поверхню - канавами й траншеями. Ресурси золота разом з розвіданими запасами становлять приблизно 11 т із середнім умістом 4,7 г/т

2.4 Родовище Майське $[2,12,21]$ розміщується в Савранському районі Одеської області, а в металогенічному плані у межах Савранського рудного поля Подільської субпровінції УЩ. Умісні породи представлені архей-протерозойськими нашарованими утвореннями: біотитовими плагіогнейсами, амфібол-біотитовими кристалосланцями, амфіболітами 3 прошарками метаультрамафітів, інколи кальцифірів, графітових і графітумісних кристалосланців. Товщу перелічених вище стратифікованих порід проривають протерозойські гранітоїдні масиви. Родовище приурочене до зони ендоконтактів Південного й Північного масивів апліт-пегматоїдних лейкократових гранітів. Зруденіння локалізується в межах флексуроподібного ускладнення північно-східного крила Савранської синкліналі. Широтно орієнтованим розломом із субвертикальним положенням зміщувача родовище умовно поділяється на дві частини: північну й південну.

Зруденіння представлено стрімкоспадними рудними зонами загальною протяжністю до 2,9 км і потужністю 100-250 м. На родовищі виокремлено й вивчено до глибини понад 500 м дві головні золотоносні зони: Північну й Південну.

Рудні тіла представлені метасоматитами кварц-біотит-олігоклазового складу [2] потужністю від 1 до 18 м і вмістом золота в середньому 5,6 г/т. Руди характеризуються низьким умістом сульфідів - 1-5 \%, що представлені переважно піротином і піритом, зрідка пентландитом, марказитом, халькопіритом, арсенопіритом, льолінгітом та ін. Ресурси золота оцінюються в 40 т із середнім його вмістом 5,6 г/т. Потужність осадового чохла, який перекриває докембрійські утворення, становить 60-120 м.

На Майському родовищі в 90-х роках XX сторіччя було пройдено шахтний стовбур завглибшки приблизно 200 м (проєктна глибина 420 м) і приблизно 250 м горизонтальних виробок. У 1998 р. розвідувальні роботи через брак фінансування було зупинено й на сьогодні гірничі виробки перебувають на “мокрій консервації'

2.5 Родовища Клинцівське та Юр'ївське [12] розміщуються в Кіровоградській субпровінції УЩ, південніше м. Кропивницький. Вони приурочені до східного екзоконтакту Новоукраїнського гранітоїдного плутону. Зруденіння кон- тролюється меридіональним розломом і локалізується в гнейсах (метатеригенних породах) палеопротерозою.

Родовище Клинцівське представлено двома золотоносними зонами субмеридіонального простягання, завширшки 70-100 м і завдовжки 2,3-5,7 км. Основний потенціал родовища пов'язується з рудною зоною, розміщеною східніше. Вона трасується процесами окварцювання, амфіболізації, біотитизації гнейсів, украпленістю й тонкими прожилками сульфідів, обсяг яких становить 1-3 \%: переважно арсенопірит і льолінгіт, а також піротин, пірит, халькопірит. У межах східної зони виокремлюється шість золото-кварцових рудних тіл потужністю 1-5 м, протяжністю до сотень метрів.

На родовищі в 90-х роках XX сторіччя пройдено два пошукові шурфи завглибшки 40 м і горизонтальні підземні розвідувальні виробки на одному з горизонтів. Розвідувальні роботи припинили через брак фінансування. Нині зусиллями ТОВ “Ліра майн мінералз” відновлено геологорозвідувальні роботи на родовищі, відкачано воду, проведено технологічне опробування головних рудних перетинів. За наявними оцінками ресурси золота становлять приблизно 47 т (зокрема й запаси понад 7 т) із середнім умістом 4,3-5,5 г/т.

Юр'івське родовище [12] розміщене в межах одного з урановорудних полів. У структурному плані воно має блокову будову, що зумовлена перетином розривних тектонічних порушень субширотного й північно-західного простягання. Виокремлюються три блоки: Південний, Центральний і Північний.

Золоторудна мінералізація приурочена до лінійних зон окварцювання протяжністю 400-1600 м і потужністю 5-17 м. Бурінням виявлено 17 віялоподібних рудних зон, що розкриваються догори. Вони представлені тектонічно переробленими вмісними породами, які зазнали калій-кремнієвих гідротермально-метасоматичних змін і розвитку сульфідної мінералізації (до 3-5 \%). У межах мінералізованих зон локалізуються рудні тіла завдовжки 50-400 м, потужністю 0,2-4 м і з умістом золота 2,8-3,9 г/т.

На Юр”ївському родовищі проведено загальні геолого-оцінювальні та інженерно-геологічні роботи для визначення місця закладення стовбура шахти. Ресурси золота становлять приблизно 12 т.

3. Карпатсько-Кримська провінція $є$ складовою частиною Середземноморського альпійського золотоносного поясу, для якого характерна золото-срібна металогенічна спеціалізація. Власне золотоносною є Карпатська субпровінція, що розміщується в крайній західній частині Украйни й охоплює як власне Карпати, так і Закарпаття. У ії межах відомі родовища Мужіївське і Сауляк [12].

Мужіївське родовище розміщується в Берегівському районі Закарпатської області. Воно локалізоване в бортовій частині вулканічної палеокальдери, складеної міоценовими туфами й туфітами з прошарками аргілітів, які прориваються інтрузіями ріолітів. Руді тіла залягають на глибині 60-150 м.

Промислову цінність родовища визначають два типи руд: власне золоті й комплексні золото-поліметалічні зі сріблом. Ближче до поверхні залягають переважно золоті руди, представлені прожилково-вкрапленими, штокверковими покладами. 3 глибиною вони поступово переходять в стрімкоспадні кварцові й адуляр-кварцові золото-поліметалічні жили. Золото в рудах міститься як у вільному, так і тонкодисперсному стані в сульфідах (у золото-поліметалічних рудах) Уміст золота в рудах змінюється в межах 4,5-15 г/т. Ресурси й запаси золота разом оцінюються в 55 т. Крім золота, у рудах містяться $\mathrm{Ag}-90$ г/т, $\mathrm{Pb}-2,1 \%, \mathrm{Zn}-5,04 \%$. 
Родовище було розвідано й підготовлено до експлуатації ще в 50-х роках XX сторіччя. Видобувати золото почали в 1999 р. в складних економічних умовах після розпаду СРСР і в період формування незалежної України. Вже у 2006 р. роботу гірничозбагачувальної фабрики було визнано нерентабельною. Загальна кількість видобутого металу становила менш як 1 т (за неофіційними джерелами 840 кг). На сьогодні роботи на родовищі відновила компанія Avellana Gold. Окрім Мужіївського родовища, компанія дістала ліцензії на геологічне вивчення й розробку в межах Берегівського та Квасівського рудоносних полів.

Родовище Сауляк розміщується в Рахівському районі Закарпатської області біля с. Ділове. Зруденіння приурочене до шар'яжно-насувної зони, представленої тектонічним меланжем і вапнисто-сланцевою олістостромою. Потужність зони варіює від 20 м до 80 м. Породний комплекс родовища вміщує протерозой-палеозойські вуглисті сланці, кварцити, біотит-хлорит-серицитові сланці, розвинені по них діафторити й філоніти; карбонатні породи, що залягають у вигляді горизонту потужністю 10-16 м.

Зруденіння розвинене вище й нижче карбонатного горизонту, власне карбонатні породи є безрудними. Мінералізація золота представлена кварцовими й кварц-карбонатними жилами та прожилками в сланцях і тектонітах. Потужність рудних тіл становить 0,4-6,8 м. За простяганням вони простежуються на 320 м, за падінням - на 260 м. Середній уміст золота в рудних тілах становить 5-10 г/т, срібла - до 30 г/т.

Родовище розвідане канавами, свердловинами колонкового буріння й підземними гірничими виробками. Запаси золота становлять 8,8 т, ресурси - 34 т.

4. Дніпровсько-Донецька провінція. Мінералізація золота розвинена в межах Донецької субпровінції, розміщеної в крайній східній частині України [12]. У геологічному плані субпровінція охоплює палеозойську складчасту споруду Нагольний кряж.

Бобриківське родовище розміщується на території Антрацитівського району Луганської області, що з 2014 р. перебуває під російською окупацією. Родовище приурочене до південного крила Бобриківської брахіантикліналі, складеної чорними карбоновими аргілітами з прошарками пісковиків і алевритів (чорносланцева формація).

Комплексне золото-срібне зі свинцем зруденіння локалізується в зонах тріщинуватості субширотних і діагональних розломів. Воно представлене кварц-анкерит-сульфідними жилами й прожилками (штокверк) і розсіяною золото-сульфідною вкрапленістю в гідротермально змінених умісних породах. Головні сульфідні мінерали: пірит, галеніт, сфалерит. Потужність рудних тіл становить від 7 до 25 м. Виявлено чотири головні рудні тіла, що супроводжуються кількома дрібнішими тілами. На глибину 30-50 м з поверхні поширені окиснені руди. Вміст золота в рудах варіює від 2 до 12 г/т, срібла $-12-188$ г/т, і свинцю - 0,7-5,7 \%.

Бобриківське родовище перебуває на стадії розвідки. На глибину 32 м запаси золота в окиснених рудах становлять приблизно 12 т. Планується його відпрацювання кар'єрним способом.

Обговорення та висновки. Україна, безумовно, має потужний золоторудний потенціал, що підтверджується наявністю не менш як десяти перспективних родовищ. Вони перебувають на різній стадії вивченості, та лише родовища Карпатської субпровінції (Мужіївське, Сауляк), а також Сурозьке родовище Приазовської провінції пройшли стадію розвідки. Водночас головні перспективи пов'язуються із зеленокам'я- ними структурами (поясами) субпровінції Середнього Придніпров'я провінції УЩ, де відкриті родовища, типові для аналогічних, промислово освоєних докембрійських регіонів світу.

За винятком Мужіївського епітермального родовища, всі інші належать до високоперспективного орогенного типу, зокрема й Бобриківське, локалізоване в чорносланцевій формації.

На наш погляд, найбільшої уваги за ресурсним потенціалом заслуговує Солонянське рудне поле. Сприятливими чинниками для залучення інвестицій та активізації геологорозвідувальних робіт у його межах є такі:

1. Зруденіння золота локалізується у високопродуктивних на золото ранньодокембрійських зеленокам'яних утвореннях. Його загальновизнаним аналогом є рудне поле Порк’юпайн у Канаді.

2. Порівняно проста геологічна будова за чіткої рудогенерувальної і рудоконтролювальної ролі субвулканічних утворень метаріодацит-плагіогранітної аполоннівсько-сергіївської ВПА, що прориває метатолеїт-габро-діабазову солонянсько-сурську ВПА.

3. Виявлено два середні за масштабом родовища Сергіївське і Балка Золота, вісім перспективних рудопроявів і понад 150 пунктів мінералізації і геохімічних аномалій золота.

4. СРП розміщується в промислово розвиненій Дніпропетровській області, яка містить світового масштабу родовища заліза (Криворізький басейн) і мангану (Нікопольський басейн), а також родовища національного рівня - титану, алюмінію та інших корисних копалин.

5. Родовища Сергіївське і Балка Золота є комплексними золото-молібденовими. Крім того, у молібденіті виявлено високий уміст Re i Os, які можна попутно вилучати як вельми дорогі компоненти.

6. У палеогенових відкладах осадового чохла (нижня частина бучацької серії) над корінними родовищами виявлені поховані алювіальні розсипи золота. На додаток до цього, у вуглистих піщано-глинистих породах верхньої частини розрізу бучацької світи локалізовані потенційно промислові концентрації урану.

Основні несприятливі чинники - забруднення довкілля. Передусім це стосується чорноземів і підземних вод. Істотний негативний вплив на економічні показники має також факт залягання руди на глибині від 30 до 100 м, що більшою мірою передбачає дорогий підземний спосіб видобутку.

У межах СРП першочерговим об'єктом для розвитку є Сергї̈вське родовище. Зазначимо, що більшість фахівців розглядає його як найперспективніше загалом в Україні. Серед переваг Сергіївського родовища такі:

1. Порівняно проста геологічна будова: рудні тіла розміщуються субпаралельно до екзоконтактів Сергївського дайкоподібного субвулканічного тіла метаріодацит-плагіогранітної солонянсько-сурської ВПА.

2. Наявність густої мережі розвідувальних свердловин, пробурених у центральній частині родовища, де зосереджені вже оцінені 10 т запасів благородного металу.

3. Середній уміст золота в рудах становить 7 г/т і більше, а робоча потужність рудних тіл -2 м.

4. На східному фланзі родовища розвинене зруденіння молібдену, представлене молібденітом, у якому виявлено високий уміст ренію й осмію.

5. Корінне зруденіння перекрите потужною корою вивітрювання й палеогеновими відкладами бучацької серії, які вміщують чималі ресурси легкозбагачуваного елювіального й алювіального золота. 
Як бачимо, Солонянське рудне поле - одне з найперспективніших, добре вивчених і забезпечених великими ресурсами золота, а також важливими супутніми корисними копалинами. Ми переконані, що успішним стартом для його освоєння і загалом для початку промислового видобутку золота в Україні стане розробка Сергіївського золото-молібденового родовища.

\section{ЛIТЕРАТУРА}

1. Бобров О. Б., Сіворонов А. О., Гурський Д. С., Лисенко О. А. Геологічна будова та золотоносність Сорокинської зеленокам'яної структури (Західне Приазов'я). - Д.: Арт-Прес:Техпечать, 2000. - 146 с.

2. Бобров О. Б., Сіворонов А. О., Гурський Д. С., Павлунь М. М., Ляхов Ю. В. Геолого-генетична типізація золоторудних родовищ України. - К.: УкрДГРІ, 2004. - 367 с.

3. Бобров А. Б. Вулкано-плутонические ассоциации зеленокаменных поясов Украинского щита (формации, палеовулканологические реконструкции, металлогения). Автореферат дис. ... доктора геол.-мин. наук. - Львов, 1994. - 40 с.

4. Бобров А. Б. Метаморфизованная риодацитовая формация зеленокаменных поясов Украинского щита. Статья 2. Палеовулканические реконструкции, металлогения//Геол. журн. - 1993. - № 5. - С. 47-58

5. Бобров А. Б. Метариодацитовая формация зеленокаменных поясов Украинского щита. Статья 1. Состав, строение и возраст// Геол. журнал. - 1993. - № 1. - С. 23-32.

6. Бобров А. Б., Сукач В. В., Малых М. М., Цыма М. Т., Монахов B. C., Абдельхак Е. А., Маслянка Т. Б. Геология и структура золоторудного месторождения Балка Золотая (Среднее Приднепровье)// Відомості АГН України. - 1997. - № 4. - С. 67-74.

7. Галещький Л. С., Чернієнко Н. М, Брагін Ю. М. та ін. Атлас “Геологія і корисні копалини України”/Під ред. Л. С. Галецького. Київ: УІЦПТ “Геос - ХХІ століття”,2001. - 168 с.

8. Гаев И. А., Гаева Н. М., Лебедь Г. Т. Проявления золота в докемрийских осадочно-вулканогенных породах Среднего Приднепровья//Геол. журнал. - 1970. - № 4. - С. 126-131.

9. Ковальчук М. С., Сукач В. В. Просторово-парагенетична, полігенно-поліхронна золоторудна система Солонянського рудного поля//Тектоніка і стратиграфія - 2018. - № 45 - С. 123-132.

10. Лазько Е. М., Сиворонов А. А., Гурский Д. С., Бобров А. Б. Металлогения архея. - Львов: ЗУКЦ, 2005. - $158 \mathrm{c}$

11. Лисенко О. А. Фактори рудолокалізації, морфологія і внутрішня будова золоторудних тіл Сурозького родовища//Збірник наукових праць УкрДГРІ. - 2008. - № 4. - С. 50-62.

12. Металічні і неметалічні корисні копалини України: у 2 т. - Т. 1 Металічні корисні копалини. - Київ-Львів: Центр Європи, 2006. - 785 с.

13. Рудько Г. І., Литвинюк С. Ф., Ловинюков В. І., Лисенко О. А Геолого-промислова характеристика золоторудних родовищ України як об'єктів геолого-економічної оцінки//Збірник наукових праць УкрДГРІ. - 2015. - № 4. - С. 43-64.

14. Сиворонов A. А. Формации и происхождение нижнедокембрийских зеленокаменных комплексов Восточно-Европейской платформы//Автореф. дис. ... докт. геол.-минерал. наук. - М., 1987. - 38 с.

15. Сукач В. В. Геологічна будова та золотоносність Солонянського рудного поля (Сурська структура, Середне Придніпров'я). Автореф. дис. .... канд. геол. наук. - Львів: ЛНУ, 2002. - 17 с.

16. Сукач В. В. Геолого-структурні обстановки локалізації зруденіння золота Солонянського рудного поля (Сурська зеленокам'яна структура, Середнє Придніпров'я)//Геохронологія та рудоносність докембрію і фанерозою: зб. тез наук. конференції. - К., 2015. - С. 116-117.

17. Сукач В. В., Ісаков Л. В., Цима М. Т. Типізація золоторудних об'єктів Солонянського рудного поля//Науковий вісник НГУ.-2005. - № 9. - C. $10-15$.

18. Сукач В. В., Некряч А. І., Бобров О. Б. та ін. Речовинний склад та стратиграфічне положення золотовміщуючої аполлонівсько-сергіївської вулкано-плутонічної асоціації (Середнє Придніпров'я, Український щит)//Геологія і магматизм докембрію Українського щита. - К., 2000. - С. 112-115.

19. Сукач В. В., Рязанцева Л. О. Комплексні золото-молібденові родовища та рудопрояви в зеленокам'яних поясах Середнього Придніпров'я Українського щита//Мінеральні ресурси України. 2018. - № 2. - C. 3-9.

20. Bobrov A. Greenstone belt metallogeny view of ore-forming role of rhiodacite-trondjemite volcanic-plutonic association, Ukrainian Shield//8-th IAGOD Sumposium. August 12-18. - 1990. - Ottava, Canada.
21. Bobrov O. B., Gurskiy D. S., Krasnozhon M. D. et al. Main types of rock complexes and mineral deposits in the Ukrainian Shield. Geological excursion guidebook. - Kyiv: Geographica, 2002. - 166 p.

\section{REFERENCES}

1. Bobrov O. B., Sivoronov A. O., Hurskyi D. S., Lysenko O. A. Geological structure and gold-bearing of Soroki greenstjne structure (West Azov region). - Donetsk: Art-Press: Techpechat, 2000. - 146 p. (In Ukrainian).

2. Bobrov O. B., Sivoronov A. O., Hurskyi D. S., Pavlun M. M., Liakhov $Y u$. V. Geological and genetic typification of gold deposits in Ukraine. - Kyiv: UkrDHRI, 2004. - 367 p. (In Ukrainian).

3. Bobrov A. B. Volcano-plutonic associations of greenstone belts of the Ukrainian Shield (formations, paleovolcanological reconstructions, metallogeny). Abstract dis.... Dr. Sci. (Geol. \& Mineral.). - Lvov, 1994. - 40 p. (In Russian).

4. Bobrov A. B. Metamorphized rhyodacitic formation of greenstone belts of the Ukrainian Shield. Article 2. Paleovolcanic reconstruction, metallogeny//Geol. zhurn. - 1993. - № 5. - P. 47-58. (In Russian).

5. Bobrov A. B. Metarhyodacitic formation of greenstone belts of the Ukrainian Shield. Article 1. Composition, structure and age//Geol. zhurn. - 1993. - № 1. - P. 23-32. (In Russian).

6. Bobrov A. B., Sukach V.V., Malyh M. M., Cyma M.T., Monahov V.S., Abdelhak E. A., Maslyanka T. B. Geology and structure of Balka Zolota gold deposit (Middle Dnipro region)//Vidomosti AHN Ukrainy. - 1997. - № 4. - P. 67-74. (In Russian).

7. Haletskyi L. S., Cherniienko N. M., Brahin Yu. M. et al. Geology and Minerals of Ukraine (Atlas)/Edited L. S. Haletskyi. - Kyiv: TOV UITSPT "Heos - XXI stolittia",2001. - 168 p. (In Ukrainian).

8. Gaev I. A., Gaeva N. M., Lebed G. T. Gold occurrences in Precambrian in sedimentary-volcanic rocks of the Middle Dnipro province// Geol. zhurn. - 1970. - № 4. - P. 126-131. (In Russian).

9. Kovalchuk M. S., Sukach V. V. Spatially-paragenetic, polygenicpolychronous gold ore system of the Solonianske ore field//Tektonika stratyhrafiia. - 2018. - № 45. - P. 123-132. (In Ukrainian).

10. Lazko E. M., Sivoronov A. A., Gurskij D. S., Bobrov A. B. Metallogeny of Archean. - Lvov: ZUKC, 2005. - 158 p. (In Russian).

11. Lysenko $O$. A. Factors of ore localization, morphology and internal structure of gold ore bodies of the Surozh deposit//Zbirnyk naukovykh prats UkrDHRI. - 2008. - № 4. - P. 50-62. (In Ukrainian).

12. Metallic and nonmetallic minerals of Ukraine: in 2 vol. - Vol. 1: Metallic minerals. Kyiv-Lviv:Tsentr Yevropy, 2006. - 785 p. (In Ukrainian).

13. Rudko H. I., Lytvyniuk S. F., Lovyniukov V. I., Lysenko O. A. Geological and industrial characteristics of Ukraine's gold deposits as objects of economic-geological evaluation//Zbirnyk naukovykh prats UkrDHRI. - 2015. - № 4. - P. 43-64. (In Ukrainian).

14. Sivoronov A. A. Formations and origin of Lower Precambrian greenstone complexes of the East-European platform. Abstract dis. .. Dr. Sci. (Geol. \& Mineral.). - Moskva, 1987. - 38 p. (In Russian).

15. Sukach V. V. Geological structure and gold-bearing of the Solone ore field (Middle Dnipro region, Sura structure). Abstract dis. ... Dr. Sci. (Geol. \& Mineral.). - Lviv: LNU, 2002. - 17 p. (In Ukrainian).

16. Sukach V. V. Geological and structural setting of gold mineralization in Solone ore field (Sura greenstone structure, Middle Dnipro region)//Heokhronolohiia i rudonosnost dokembriiu ta fanerozoiu: $\mathrm{zb}$. tez nauk. konferentsii. - Kyiv, 2015. - P. 116-117. (In Ukrainian).

17. Sukach V.V., Isakov L. V., Tsyma M. T. Typification of gold ore objects of Solone ore field//Naukovyi visnyk NHU. - 2005. - № 9. - P. 10-15. (In Ukrainian).

18. Sukach V. V., Nekriach A. I., Bobrov O. B., Malykh M. M., Monakhov $V$. S. Rock composition and stratigraphy of gold-bearing Apollonivka-Serhiivka volcano-plutonic assosiation (Middle Dnipro region, Ukrainian Shield)//Heolohiia i mahmatyzm dokemriiu Ukrainskoho shchyta. - Kyiv, 2000. - P. 112-115. (In Ukrainian).

19. Sukach V. V., Riazantseva L. O. Complex gold-molybdenum deposits and occurrences in greenstone belts of the Middle Dnipro region of the Ukrainian Shield//Mineralni resursy Ukrainy. - 2018. - № 2. P. 3-9. (In Ukrainian).

20. Bobrov A. Greenstone belt metallogeny view of ore-forming role of rhiodacite-trondjemite volcanic-plutonic association, Ukrainian Shield//8-th IAGOD Symposium. August 12-18. - 1990. - Ottava, Canada.

21. Bobrov O. B., Gurskiy D. S., Krasnozhon M. D. et al. Main types of rock complexes and mineral deposits in the Ukrainian Shield. Geological excursion guidebook. - Kyiv: Geographica, 2002. - 166 p.

Руко пи с о тримано 19.08.2021. 